\title{
Pemberian Konsentrasi Benzyle Amino Purine (BAP) dan Inokulan Bradyrhizobium japonicum terhadap Pertumbuhan Bintil Akar Tanaman Kedelai Hitam
}

\author{
Rama Adi Pratama, Kiki Zakiah \\ Fakultas Pertanian, Universitas Garut \\ ramatarigan@uniga.ac.id
}

\begin{abstract}
ABSTRAK
Kedelai (Glycine $\max$ (L.) Merril) merupakan tanaman pangan yang penting sebagai sumber protein nabati. Penelitian ini akan dilakukan di Kecamatan Tarogong Kaler Kabupaten Garut. Tujuan penelitian ini adalah untuk mengetahui pengaruh pemberian BAP dan PGPR terhadap jumlah bintil akar total dan jumlah bintil akar efektif. Lokasi penelitian berada pada ketinggian tempat 650 meter. Rancangan pada penelitian ini menggunakan Rancangan Acak Kelompok (RAK) Faktorial yang terdiri dari 2 faktor yaitu empat taraf konsentrasi Benzyle Amino Purine (BAP) dan empat taraf inokulan Bradyrhizobium japonicum. Tiap perlakuan diulang sebanyak dua kali, maka jumlah keseluruhan : 4 x 4 × $2=32$. Hasil menunjukkan tidak terjadi interaksi pemberian konsentrasi BAP dan Bradyrhizobium japonicum namun memberikan pengaruh mandiri terhadap masing-masing pemberian pengaruh tersebut.
\end{abstract}

Kata Kunci : Kedelai, BAP, bradyrhizobium

\begin{abstract}
Soybean (Glycine max (L.) Merril) is an important food crop as a source of vegetable protein. This research will be conducted in Tarogong Kaler District, Garut Regency. The purpose of this study was to determine the effect of BAP and PGPR administration on the total number of root nodules and the number of effective root nodules. The research location is at a height of 650 meters. The design in this study uses Factorial Randomized Block Design (RBD) which consists of two factors, namely four levels of Benzyle Amino Purine concentration (BAP) and four levels of inoculant Bradyrhizobium japonicum. Each treatment was repeated twice, then the total number: $4 \times 4 \times 2=32$. The results showed that there was no interaction between the concentration of BAP and Bradyrhizobium japonicum but had an independent effect on each of these effects.
\end{abstract}

Keyword: Soybean, BAP, bradyrhizobium 


\section{PENDAHULUAN}

Kedelai (Glycine $\max (\mathrm{L}$.$) Merril) merupakan tanaman pangan yang$ penting sebagai sumber protein nabati. Kedelai juga merupakan komoditas yang telah dibudidayakan di Indonesia sebagai bahan baku industri pangan dan non pangan. Di Indonesia terdapat dua macam kedelai yang berkembang, yaitu kedelai kuning dan kedelai hitam. Kedelai kuning memiliki kandungan lemak lebih tinggi, sehingga sering digunakan sebagai bahan baku pembuatan minyak kedelai. Kedelai hitam memiliki kandugan lemak yang lebih rendah dan memiliki kandungan protein lebih tinggi. Kedelai hitam merupakan bahan baku utama dalam industri kecap.

Kedelai hitam mempunyai kandungan fenolik, tanin, antosianin dan isoflavon serta aktivitas antioksidan lebih tinggi dibanding kedelai kuning ( $\mathrm{Xu}$ dan Chang, 2007). Menurut Xu dan Chang (2007) kedelai hitam kandungan flavonoidnya 6 kali lebih banyak dibanding kedelai kuning (kandungan total flavonoid kedelai kuning dan hitam berturut-turut 0,41 dan 2,57 mg ekuivalen dengan katekin per gram) dan aktivitas antioksidan 15 kali lebih tinggi (DPPH scavenging capacity kedelai kuning dan hitam berturut-turut 1,40 dan 17,58 $\mu \mathrm{mol}$ ekuivalen Trolox per gram) sedangkan menurut Astadi dkk, (2009) kulit kedelai hitam varietas Mallika memiliki kandungan antosianin 1,36 g/100 g dan senyawa fenolik 6,46 g/100 g.

Berkembangnya industri kecap di Indonesia secara langsung berpengaruh terhadap peningkatan kebutuhan akan kedelai hitam. Berdasarkan laporan Badan Pusat Statistik bahwa produksi kedelai pada tahun 2014 adalah 15,51 kuintal per hektar meningkat sebanyak 1,16\% menjadi 15,69 kuintal per hektar pada tahun 2015 (Badan Pusat Statistik, 2016). Walaupun terjadi peningkatan hal tersebut masih belum dapat mencukupi kebutuhan akan kedelai nasional. Rendahnya tingkat produktivitas ini menyebabkan tidak terpenuhinya kebutuhan kedelai dalam negeri dengan kondisi permintaan dan kebutuhan masyarakat dari tahun ke tahun yang terus meningkat seiring dengan bertambahnya jumlah penduduk. Oleh karena itu, perlu adanya peningkatan mutu benih untuk menghasilkan produktivitas yang tinggi dengan mutu benih yang tinggi pula, sehingga 
ketersediaan benih bermutu dapat terwujud dalam rangka mendukung swasembada kedelai.

Ketersediaan varietas benih kedelai hitam yang bermutu itu sendiri jumlahnya masih terbatas. Faktor pembatas produksi kedelai salah satunya adalah benih yang bermutu (Anggraeni dan Suwarno, 2013). Menurut Baihaki (2002) bahwa penggunaan benih kedelai yang bersertifikat oleh petani masih sangat rendah yaitu sekitar 5\%. Cara yang dapat dilakukan untuk mendapatkan varietas yang unggul yaitu melalui seleksi, introduksi dan persilangan. Adanya perbedaan respon genotipe terhadap lingkungan menyebabkan timbulnya perbedaan fenotipe pada setiap tanaman. Dari penampilan fenotipe tersebut suatu perbedaan sifat karakter dapat diketahui apakah di pengaruhi oleh genetik atau lingkungan sehingga dapat memudahkan pemulia untuk melakukan proses seleksi setiap genotipe untuk mengetahui genotipe yang lebih baik pada suatu daerah (Welsh, 2005).

Selain pemilihan benih yang bermutu, aspek budidaya dan kualitas tanah juga harus diperhatikan. Kedelai sebagai tanaman semusim menyerap N, P dan K dalam jumlah relatif besar. Untuk mendapatkan hasil kedelai yang tinggi diperlukan hara mineral dalam jumlah yang cukup dan seimbang. Namun demikian, pemberian pupuk anorganik secara intensif dan bahan lain yang kurang ramah terhadap tanah akan mengakibatkan kondisi tanah menurun dan tergolong lahan sakit. Oleh karena itu, pemberian pupuk anorganik harus diimbangi dengan pemberian pupuk organik dan pupuk hayati.

Pupuk organik berperan penting dalam meningkatkan serta mempertahankan kualitas tanah. Pupuk hayati juga membantu meningkatkan efisiensi serapan hara, memperbaiki pertumbuhan dan hasil tanaman, serta meningkatkan ketahanan hama dan penyakit. Kualitas tanah dan serapan yang baik akan menopang pertumbuhan dan produktivitas tanaman. Pupuk hayati mengandung mikroorganisme yang berguna bagi tanaman.

Salah Salah satu kelebihan dari tanaman kacang-kacangan yaitu mampu bersimbiosis mutualisme dengan bakteri rhizobium sebagai penyedia nitrogen. Salah satu bakteri rhizobium adalah Bradyrhizobium japonicum. B japonicum juga termasuk bakteri yang hidup disekitar rhizosphere maka dapat dikatan bakteri 
ini bagian dari plant growth promoting rhizobacteria. Fungsinya yaitu membantu dalam pertumbuhan dan produksinya tanaman serta membantu secara bertahap dalam memulihkan kesuburan tanah. Beberapa bakteri dari kelompok PGPR adalah bakteri penambat nitrogen seperti genus Rhizobium, Azotobacter, Azospirillum dan bakteri pelarut fosfat seperti genus Bacillus, Pseudomonas, Arthrobacter, Bacterium dan Mycobacterium (Biswas et al, 2000).

Bradyrhizobium japonicum adalah salah satu jenis bakteri bintil akar (BBA) yang berperan penting dalam meningkatkan produktivitas tanaman kedelai secara simbiosis. Bintil akar merupakan proses kompleks yang membutuhkan koordinasi ekspresi kedua gen bakteri dan tanaman. Flavonoid dalam eksudat akar tanaman menginduksi ekspresi dari gen bintil di Bradyrhizobium (Smith dan Wollum, 1989). Di dalam bintil, BBA mengubah nitrogen menjadi amonia sebagai suplai nitrogen bagi pertumbuhan tanaman (Atlas dan Bartha,1981). Bradyrhizobium japonicum juga menghasilkan lendir dari karbohidrat permukaan sel yang sebagian besar berupa polisakarida ekstraseluler (EPS ) dan berfungsi sebagai toleransi terhadap asam (Lounch dan Miller, 2001)

Sitokinin (BAP) berfungsi sebagai perangsang pertumbuhan tunas, berpengaruh terhadap metabolisme sel, pembelahan sel, merangsang sel, mendorong pembentukan buah dan biji, mengurangi dormansi apikal, serta mendorong inisiasi tunas lateral (Wattimena, et al, 1992).

Sitokinin merupakan nama kelompok hormon tumbuh yang sangat penting sebagai pemacu pertumbuhan dan morfogenesis dalam kultur jaringan seperti halnya pada auksin, selain sitokinin alami juga terdapat sintetisnya yang tergolong dalam zat pengatur tumbuh (Santoso dan Fatimah, 2005).

Sitokinin merupakan senyawa organik yang menyebabkan pembelahan sel yang dikenal dengan proses sitokinesis. Sitokinin mempengaruhi berbagai proses fisiologis di dalam tanaman terutama mendorong pembelahan sel. Salah satu jenis ZPT dari golongan sitokinin yang sering dipakai dalam kultur jaringan yaitu BAP (6-benzylaminopurine). 6-Benzilaminopurine (BAP) merupakan salah satu sitokinin sintetik yang aktif dan daya merangsangnya lebih lama karena tidak mudah dirombak oleh enzim dalam tanaman. Penggunaan BAP dengan konsentrasi tinggi dan masa yang panjang dapat menentukan kemampuan 
pembentukan jumlah tunas dan bentuk tunas. Pada konsentrasi BAP yang lebih tinggi dan masa induksi yang lebih lama menyebabkan penampakan abnormal dan menyebabkan penurunan jumlah regenerasi yang diperoleh (Gunawan, 1995).

Aktivitas sitokinin tergantung juga dari aktivitas fitohormon yang lainnya, terutama auksin baik dalam efek menghambat maupun efek yang mendorong pembelahan sel (Wattimena, et al, 1992). Sitokinin dan auksin memiliki peran yang sangat penting dalam hal menginduksi tunas adventif. Nisbah keduanya akan menentukan apakah suatu kalus akan membentuk tunas adventif, akar, atau tunas adventif dan akar (Armini, et al, 1991).

\section{METODE PENELITIAN}

Penelitian ini akan dilakukan di Kecamatan Tarogong Kaler Kabupaten Garut. Lokasi penelitian berada pada ketinggian tempat 650 meter. Rancangan pada penelitian ini menggunakan Rancangan Acak Kelompok (RAK) Faktorial yang terdiri dari 2 faktor yaitu empat taraf Konsentrasi BAP dan empat taraf inokulan Bradyrhizobium japonicum. Tiap perlakuan diulang sebanyak dua kali, maka jumlah keseluruhan : 4 × 4 × $2=32$

\section{HASIL DAN PEMBAHASAN}

Berdasarkan hasil analisis menunjukkan tidak terjadi interaksi antara pengaruh konsentrasi BAP dan Bradyrhizobium japonicum terhadap jumlah bintil akar total. Namun memberikan pengaruh mandiri dari masing-masing perlakuan yang diberikan. Hasil analisis terdapat pada Tabel 1.

Tabel 1. Hasil Analisis Konsentrasi BAP dan Bradyrhizobium japonicum terhadap Jumlah Bintil Akar Total

\begin{tabular}{ll}
\hline Perlakuan & $\begin{array}{c}\text { Jumlah Biji Bintil Akar Total } \\
\text { (butir) }\end{array}$ \\
\hline Konsentrasi POC Rumput Laut (P) & \\
$\mathrm{p}_{1}=0 \mathrm{ppm}$ & $17,50 \mathrm{a}$ \\
$\mathrm{p}_{2}=0.4 \mathrm{ppm}$ & $19,38 \mathrm{ab}$ \\
$\mathrm{p}_{3}=0.8 \mathrm{ppm}$ & $22,25 \mathrm{c}$ \\
$\mathrm{p}_{4}=1.2 \mathrm{ppm}$ & $20,00 \mathrm{bc}$ \\
\hline
\end{tabular}




$$
\begin{array}{rr}
\hline \text { Inokulan Bradyrhizobium japonicum }(\mathrm{B}) & \\
\mathrm{b}_{1}=\text { tanpa isolat B. japonicum } & 18,50 \mathrm{a} \\
\mathrm{b}_{2}=\text { B. japonicum } 10^{5} & 18,75 \mathrm{ab} \\
\mathrm{b}_{3}=\text { B. japonicum } 10^{6} & 21,00 \mathrm{~b} \\
\mathrm{~b}_{4}=\text { B. japonicum } 10^{7} & 20,88 \mathrm{~b}
\end{array}
$$

Keterangan: Angka rata-rata yang diikuti huruf yang sama pada setiap kolom, tidak berbeda nyata menurut Uji Jarak Berganda Duncan pada taraf 5\%.

Hasil menunjukkan bahwa jumlah bintil akar berpengaruh terhadap pemberian BAP. Nilai tertinggi terdapat pada pemberian BAP pada konsentrasi $0,8 \mathrm{ppm}\left(\mathrm{p}_{3}\right)$ yaitu 22,25. Sedangkan pada perlakuan pemebrian inokulan $B$. japonicum $10^{6}$ dengan nilai 21 . Namun tidak berbeda nyata dengan $B$. japonicum $10^{7}$ dengan nilai 20,88 .

Berdasarkan hasil analisis menunjukkan tidak terjadi interaksi antara pengaruh konsentrasi BAP dan Bradyrhizobium japonicum terhadap jumlah bintil akar total. Namun memberikan pengaruh mandiri dari masing-masing perlakuan yang diberikan. Hasil analisis terdapat pada Tabel 1.

Tabel 2. Hasil Analisis Konsentrasi BAP dan Bradyrhizobium japonicum terhadap Jumlah Bintil Akar Efektif

(butir)

\begin{tabular}{rl}
\hline Konsentrasi BAP $(\mathrm{P})$ & \\
$\mathrm{p}_{1}=0 \mathrm{ppm}$ & $6,00 \mathrm{a}$ \\
$\mathrm{p}_{2}=0.4 \mathrm{ppm}$ & $7,63 \mathrm{~b}$ \\
$\mathrm{p}_{3}=0.8 \mathrm{ppm}$ & $8,75 \mathrm{~b}$ \\
$\mathrm{p}_{4}=1.2 \mathrm{ppm}$ & $8,75 \mathrm{~b}$ \\
\hline Inokulan Bradyrhizobium japonicum $(\mathrm{B})$ & \\
$\mathrm{b}_{1}=$ tanpa isolat $B$. japonicum & $6,38 \mathrm{a}$ \\
$\mathrm{b}_{2}=$ B. japonicum $10^{5}$ & $9,88 \mathrm{a}$ \\
$\mathrm{b}_{3}=$ B. japonicum $10^{6}$ & $8,88 \mathrm{~b}$ \\
$\mathrm{~b}_{4}=$ B. japonicum $10^{7}$ & \\
\hline Keterangan: Angka rata-rata yang diikuti huruf yang sama pada setiap kolom, tidak
\end{tabular}


Hasil menunjukkan bahwa jumlah bintil akar berpengaruh terhadap pemberian BAP. Nilai tertinggi terdapat pada pemberian BAP pada konsentrasi $0,8 \mathrm{ppm}\left(\mathrm{p}_{3}\right)$ yaitu 8,75 . Sedangkan pada perlakuan pemebrian inokulan $B$. japonicum $10^{6}$ dengan nilai 9 . Namun tidak berbeda nyata dengan B. japonicum $10^{7}$ dengan nilai 8,88 .

\section{KESIMPULAN}

1. Tidak terjadi interaksi antara pemberian konsentrasi Benzyle Amino Purine (BAP) dan Bradyrhizobium japonicum terhadap jumlah bintil akar total dan jumlah bintil akar efektif.

2. Terdapat pengaruh mandiri pemberian Benzyle Amino Purine (BAP) dan Bradyrhizobium japonicum terhadap jumlah bintil akar total dan jumlah bintil akar efektif.

\section{DAFTAR PUSTAKA}

Adisarwanto, 2008. Budidaya Kedelai Tropika. Penebar Swadaya. Jakarta.

Astadi, I.R., M. Astuti, U. Santoso and P.S. Nugraheni. 2009. In vitro antioxidant activity of anthocyanins of black soybean seed coat in human low density lipoprotein (LDL). Food Chem., 122: 659-663.

Anggraeni, N. D dan Faiza C. Suwarno, 2013. Kemampuan Benih Kedelai (Glycine max L.) untuk Mempertahankan Viabilitasnya setelah Didera dengan Etanol. Agrohorti. 1(4):34-44

Badan Pusat Statistik, 2016. Produksi Tanaman Kedelai Indonesia. http//www.bps.go.id/ (Diakses 23 Maret 2016)

Barber, Stanley A. 1984. Soil Nutrient Bioavailability. Wiley Interscience Publication. United States of America.

Baihaki, A. 2002. Review Pemuliaan Tanaman dalam Industri Perbenihan Indonesia. Di dalam: E. Murniati dkk, Editor. Industri Benih di Indonesia Aspek Penunjang Pengembangan. Bogor (ID): Institut Pertanian Bogor. Hlm 1-6 
Biswas JC, Ladha JK, Dazzo FB. 2000. Rhizobial inoculation improves nutrient uptake and growth of lowland rice. Soil Sci. Soc.Am. J. 64:1644-1650

Dupponois, Robin. 2006. Mycorrhiza Helper Bacteria : Their Ecological Impact in Mycorrhizal Symbiosis. Handbook of Microbial Fertilizers. The Haworth Press, Inc. United States of America.

Dupponois, Robin and Garbaye. 1990. Some Mechanisms Involved in Growth Stimulation of Ectomycorrhizal Fungi by Bacteria. Canadian Journal of Botany 68: 2148 - 2152.

Fernando D, Nakkeeran, Zhang Yilan. 2005. biosynthesis of antibiotics by PGPR and its relation in biocontrol of plant diseases.dalam: Z.A. Siddiqui (ed.), PGPR: Biocontrol and Biofertilization 67-109. Springer, Dordrecht, The Netherlands

Lounch, H.A. \& Miller, K.J. 2001. Synthesis of a low-molecular-weight form of exopolysaccharide by Bradyrhizobiumjaponicum USDA 110. Appl Environ Microbiol., 67, 1011- 1014

Welsh, J.R., 2005. Fundamentals of Plant Gnenetics and Breeding. John Willey and Sons, New York. 453 pp.

Xu, B.J. and S.K.S. Chang. 2007. A Comparative study on phenolic profils and antioxidant of legums as affected by extraction solvents. J. Food Sci.,72(2):159-166. 